\title{
ラジオアイソトープ（R．I）標識抗生物質の体内分布に関する研究
}

\author{
第 1 編：液体シンチレーションカウンターによる R.I 標識抗生物質の生体試料の測定法
}

伊藤弘

Study on distribution of radioisotope-labelled antibiotics in the body.

I. Determination of radioisotope-labelled antibiotics in biological

samples by means of the liquid scintillation counter.

Hiromu Iто

I. 緒

言

抗生物質の定量法には，生物学的定量法（重層法”, 薄層カップ法 ${ }^{2}$, 帯培養法 ${ }^{3)}$, 払散法4) , 化学定量法 (值 接呈色法(5), ジアゾ連結定量法6)，放射線同位元素標識抗 生物質による体内分布測定法などがある77,87,99.

一般に応用範囲の広さ，直接抗菌力と結びついている 理由から, 主に生物学的測定法による血液, 組織内濃度 に関する基礎的，臨床的測定が盛んに打こなわれてきた。 しかし生物学的測定法にも種々なる問題がある.それは 使用する検定菌の種類により，測定值に大きな変動があ るほか，生体に括ける代謝や不活珄化の問題も当然考兄 られる(10)ので，その測定値に誤差が生じること，また動 物実験において，人体の投与量よりも比較的大量に投与 しなければならない，換言すれば末端組織内の微量測定 ができないといった欠点も見られる. 化学定量法におい ては，測定できる抗生物質の種類に限界がある。

近年, 放射線同位元素の開発, 発展により薬物の代謝, 生体内変換, 吸収, 排泄, 分布に拈ける実験的研究にも, 放射線同位元素は広く応用され，動物実験に括いても， 陌床薬用量またはそれ以下の量を投与した時の組織内浱 度の微量測定も可能になり $\mathrm{mcg}$ 以下のレペルで追跡で きるようになった，また，測定值に対する信頼度が高い こと，実験操作が容易であることなどもあって，放射線

带知学院大学歯学部第 2 口㫟外科学教室 (主任: 河合幹教授) Second Department of Oro-Maxillo-Facial Surgery, School of Dentistry, Aichi-Gakuin University

(Chief : Prof. Tsuyoshi Kawai)

受付 昭和 48 年10月29日
同位元素摽識抗生物質を使用しての体内分布に関する実 験的研究も次第に多〈なってきた7),8),97,10),11),12).

標識抗生物質の体内分布の検定には，Macro Autoradiography による定性的分布を知る場合と，Gas-flower counter や Liquid Scintillation counter (液体シンチレ ーションカウンター）に上る定量的分布を知る場合があ る.

著者は，臨床的に頻用されている抗生物質にラジオア イソトープ $\left({ }^{3} \mathrm{H},{ }^{14} \mathrm{C}\right)$ で標識し，その体内分布に関する 実験に拈いて，Solubilization Method ${ }^{13) \sim 16)}$ を使用して の液体シンチレーションカウンター測定法が適するか否 か検討し，いささかの知見を得たので報告する。

II. Solubilization Method による液体シンチ レーションカウンター測定法に対する検討

薬物による生体内の吸収，排泄，分布なとの代謝領域 にす低エネルギーの $\beta$ 線である ${ }^{3} \mathrm{H},{ }^{14} \mathrm{C}$ は盛んに利用 されているが，測定法の面で種々な困難がある。このよ らな $\beta$ 線の測定には, 液体シンチレーションカウンター 測定装置が適しているが, 測定のための生体試料（組織, 血液, 尿, 排泄物等) の処理法が繁隻で複雑をきわめて いる.

著者は，1）すべての組織にも適用できる，2）試料 調整が簡単で迅速である．3）水溶液の測定に適してい ることなどを考虙に入れ，溶解補助剤であるシンチラミ

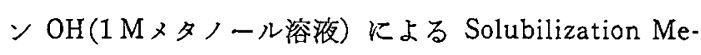
thod 使用して試料の処理, quenching 現象の減少, 测定効率のよい正確な测定などにつき検討を行った。 
1. シンチレーター添加量に対する測定効率の影響

a ) 実験試薬

R. I 標識抗生物質： ${ }^{3} \mathrm{H}$-Lincomycin, ${ }^{14} \mathrm{C}-$ Benzyl penicillin

溶解補助剂：シンチラミン $\mathrm{OH}(1 \mathrm{M}$ メタノール溶液, 和光純薬)

シンチレーター：Toluen シンチレーター（特級 Toluen $1000 \mathrm{ml}$, 米山製薬, ppo $4 \mathrm{~g}$, popop $100 \mathrm{mg}$, 和 光純薬)

標準液 : ${ }^{3} \mathrm{H}-$ Toluen 標準液 (NENC 製), ${ }^{14} \mathrm{C}$-Toluen 標準液 (NENC 製)

b ）测定装置: Beckman 液体シンチレーションカウ ンター LS 100 型,

\section{c ）実験方法}

液体シンチレーション測定用バィアル $(20 \mathrm{~m} l$ 容器) に各々 $1 \mathrm{ml}, 2 \mathrm{ml}$ のシンチラミン $\mathrm{OH}$ 溶液を入れ, 次 に ${ }^{3} \mathrm{H}$-Lincomycin 水溶液 $0.5 \mathrm{ml}(0.00375 \mathrm{mci})$ を加 え, さらに Toluen シンチレーター, $1 \mathrm{ml}$ から $12 \mathrm{ml}$ までの各段階量を添加し，よく摫找混和し，シンチレー ター添加量に対する測定効率を測定した．同様な方法で， ${ }^{14} \mathrm{C}$-Benzyl penicillin 水溶液 $0.5 \mathrm{ml}(0.00188 \mathrm{mci})$ の シンチレーター添加量に対する測定効率を測定した．测 定効率の測定には，おのおのの検液に ${ }^{3} \mathrm{H}$-Toluen 標準 液 (NENC 製)， ${ }^{14} \mathrm{C}$-Toluen 標準液 (NENC 製) を添 加して内部標準法で測定した。

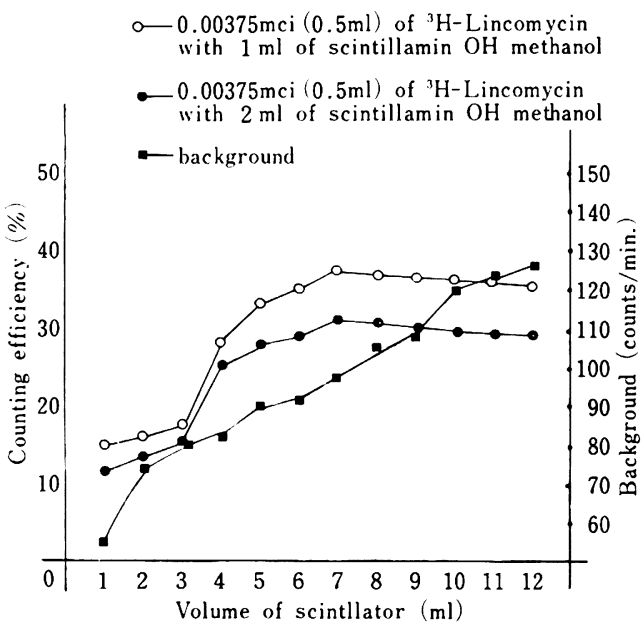

Fig. 1 Effect of increasing the volume of scintillator on the counting efficiency for a ${ }^{3} \mathrm{H}$-Lincomycin in aques solution blended with scintillamin $\mathrm{OH}$ methanol

d）実験成績

Fig. 1, Fig. 2 に示すごとく, background が $100 \mathrm{cpm}$ (Counter per minute) 以下で, 測定效率の高いのは,

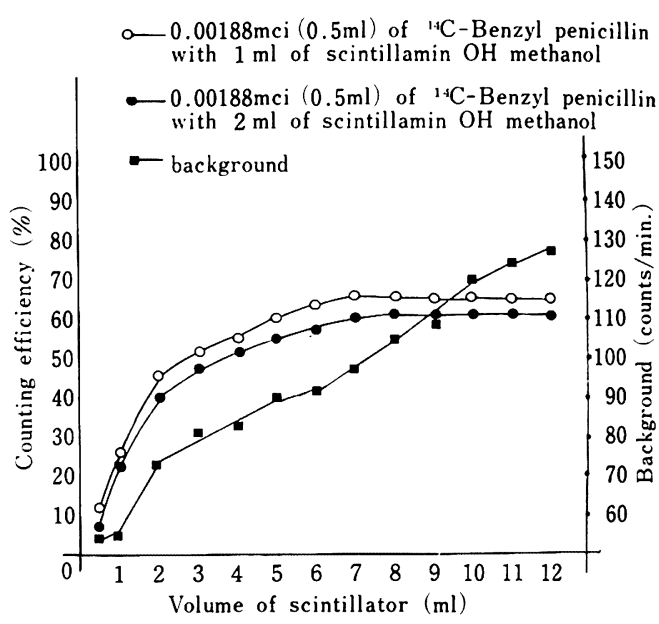

Fig. 2 Effect of increasing the volume of scintillator on the counting efficiency for a ${ }^{14} \mathrm{C}$-Benzylpenicillin in aques solution blended with scintillamin $\mathrm{OH}$ methanol

$1 \mathrm{~m} l$ のシンチラミン $\mathrm{OH}$ 溶液と $7 \mathrm{ml}$ の Toluen シン チレーター添加量であった. ${ }^{3} \mathrm{H}$-Lincomycin $0.5 \mathrm{ml}$ で $37.5 \%$ の最高効率, ${ }^{14} \mathrm{C}$-Benzyl penicillin $0.5 \mathrm{ml}$ の 66 $\%$ 最高効率を得た。次に、シンチラミン OH 溶液を $2 \mathrm{ml}$ に増加すると，測定効率の減少は， ${ }^{3} \mathrm{H}$ で約 $12 \% ，{ }^{14} \mathrm{C}$ で約 $5 \%$ であった. Toluen シンチレーター添加量が $7 \mathrm{ml}$ 以上でも測定効率はそれほど減少しない.

\section{R.I 標識抗生物質溶液量に対する測定効率の影}

a ）実験試薬：II-1 の実験と同じものを使用

b ）測定装置 : II-1 の実験と同じものを使用

c ）実験方法

${ }^{3} \mathrm{H}$-Lincomycin 水溶液量を $0.5 \mathrm{ml}, 1 \mathrm{ml}$ の 2 種類を

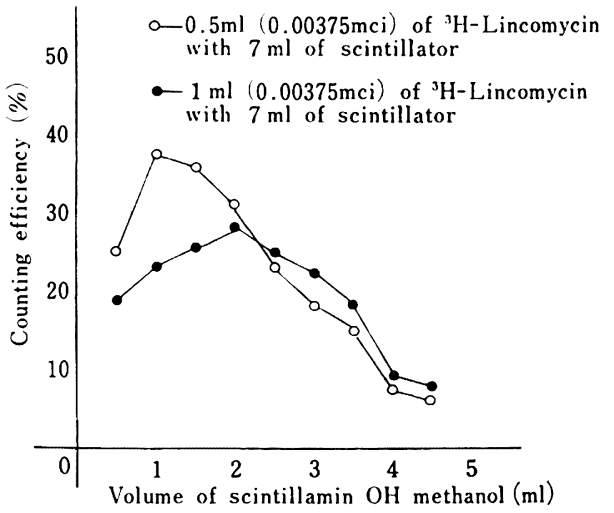

Fig. 3 Effect of scintillamin $\mathrm{OH}$ methanol and Sample volume on the counting efficiency for ${ }^{3} \mathrm{H}$-Lincomycin 
検液として，おのおのを测定用バイアルに入れ，Toluen シンチレーター $7 \mathrm{ml}$ 添加し，よく罟找し， シンチラミ ソ $\mathrm{OH}$ 溶夜の添加量を $0.5 \mathrm{ml}$ から $4.5 \mathrm{ml}$ までに種々 な混和溶解した場合の測定効率を測定した. 同様に ${ }^{14} \mathrm{C}$ Benzyl penicillin 水溶液量を $0.5 \mathrm{ml}, 1 \mathrm{ml}$ の 2 種類の 測定効率を测定した。

d）実験成績

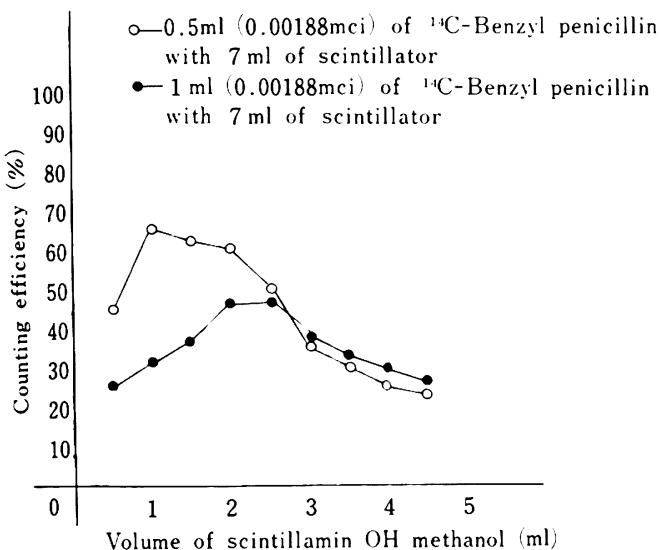

Fig. 4 Effect of scintillamin $\mathrm{OH}$ methanol and Sample volume on the counting efficiency for a ${ }^{14} \mathrm{C}$-Benzyl penicillin

Fig. 3, Fig. 4 に示すごとく, ${ }^{3} \mathrm{H}$-Lincomycin $0.5 \mathrm{ml}$ 水溶夜はシンチラミン $\mathrm{OH} 1 \mathrm{ml}$ で $37.5 \%$ の最高効率を 示し, ${ }^{3} \mathrm{H}$-Lincomycin $1 \mathrm{ml}$ 水溶液では, シンチラミン $\mathrm{OH} 2 \mathrm{ml}$ で $28 \%$ の最高効率を得た. ${ }^{14} \mathrm{C}$-Benzyl penicillin $0.5 \mathrm{ml}$ 水溶液はシンチラミン $\mathrm{OH}$ 溶液 $1 \mathrm{~m} l$ で 65 $\%$ の最高効率を示し, ${ }^{14} \mathrm{C}$-Benzyl penicillin $1 \mathrm{ml}$ 水溶 液では, シンチラミン $\mathrm{OH}$ 溶液 $2.5 \mathrm{ml}$ で $45 \%$ の最高 効率を得た。

3. 添加組織重量に対する測定効率の影響及び Toluen 系における至適重量の決定

a) 実験試薬：II-1 の実験と同じものを使用.

b) 測定装置 : II-1 の実験と同じものを使用.

c ）実験方法

dd 系雄マウス（生後 $25 \mathrm{~g}$ 前後）の各組織（脳, 舌, 颚骨, 心, 肺, 腎, 脾, 肝, 太腿骨を摘出し, それぞれ の組織を化学天科で $50 \mathrm{mg}, 100 \mathrm{mg}, 200 \mathrm{mg}$ を確実に 科量し，血液については，凝固反応を起こす前に速やか に採血したものより，0.2 $\mathrm{m} l, 0.4 \mathrm{ml}, 1 \mathrm{~m} l$ を科量し， 各組織, 血液を共栓試験管 $(5 \mathrm{~m} l$ 容器) に入れ，おのお のにシンチラミン $\mathrm{OH}$ 溶夜 $1 \mathrm{~m} l$ を添加し, $55^{\circ} \mathrm{C}$ で 24 時間, 恒温槽で浸盪しつつ加熱溶解し，その溶解液に ${ }^{3} \mathrm{H}$-Lincomycin $0.5 \mathrm{ml}(0.00375 \mathrm{mci})$ を添加し, よく
摫抖後，测定用パィアルに移し，Toluen シンチレー ター $7 \mathrm{ml}$ を加え効率を測定した. 效率の測定は, 内部標 準法にて施行した. 同様な方法で ${ }^{14} \mathrm{C}$-Benzyl penicillin の効率を测定した。ささらに测定した試料重量における 効率を乘じたものを Merit 值として算定し, Merit 值 が最高になる点をToluen 系に㧍ける至適重量とした (Table 1, 2).

\section{d ）军験成綪}

Table 1，2 に示すごとく，各組織 $50 \mathrm{mg}$, 血液 0.2 $\mathrm{m} l$ で測定効㳂よく, 各組織, 血液の重量が增加するに つれて測定効率は減少する。 Toluen 采の至連重量は, 各組織に扣いては $100 \mathrm{mg}$ 科量, および血液に扣いては $0.4 \mathrm{~m} l$ であった.

以上の予備実験により，R.I 標識抗生物質の体内分 布に関する実際的実験において，次のような方法を採用 した。体重 $25 \mathrm{~g}$ 前後の dd 系雄マウス 3 匹を 1 群とし て，マウス腹腔内に R. I 標識抗生物質をマウス $\mathrm{g}$ 重量 あたり $10 \mathrm{mcg}$ の割合で注射し，注射後 5 分，10分， 15 分, 20 分, 30 分, 60 分, 120 分後に頸部を切断して, 屠 殺し, 各臓器 (脳, 舌, 買骨, 心, 肺, 肝脾, 腎, 太腿 骨)を摘出し，化学天科にて $100 \mathrm{mg}$ を確些に科量し，組 織に付着した血液を精製水にて充分に水洗し，血液につ いては，凝固反応を起こす前に $0.4 \mathrm{ml}$ 採血し，各組織， 血液をシンチラミン $\mathrm{OH}$ 溶液 $1 \mathrm{~m} l$ を加えた共栓試験管 $\left(5 \mathrm{~m} l\right.$ 容器) 内に入れ, 恒温槽にて, $55^{\circ} \mathrm{C}, 24$ 時間浸澄し つつ加熱し，組織，血液を溶解後，30\% $\mathrm{H}_{2} \mathrm{O}_{2}$ を 1 滴ず つ加え, 脱色し, その溶解夜を液体シンチレーターカウ ンターハイアルに移し, Toluen シンチレーター溶液 7 $\mathrm{m} l$ を加え， 2 時間暗箱中に静置し, Beckman 製液体シ ンチレーションカウンターにて c. p.m. (Counter per minute) を测定した. 同様な方法で, 無投与マウスの各 臓器 $100 \mathrm{mg}$ および血液 $0.4 \mathrm{~m} l$ を摘出し，おのおのに $0.5 \mathrm{~m} l$ の R.I 標識抗生物質水溶液を添加 L, c. p. m. を测定した。

各組織内濃度および血液内濃度の算定は次の式によっ ておこならことができる。

算定方法 :

既知 R.I 標識抗生物質量

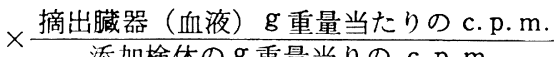

\section{III. 総括および考按}

化学療法剤の蔵器, 組織内への移行と分布に関寸る基 礎的研究は, 主に生物学的定量法を使用しての報告が多 (17) 21). しかし近年になって, 放射線同位元素の発展, 

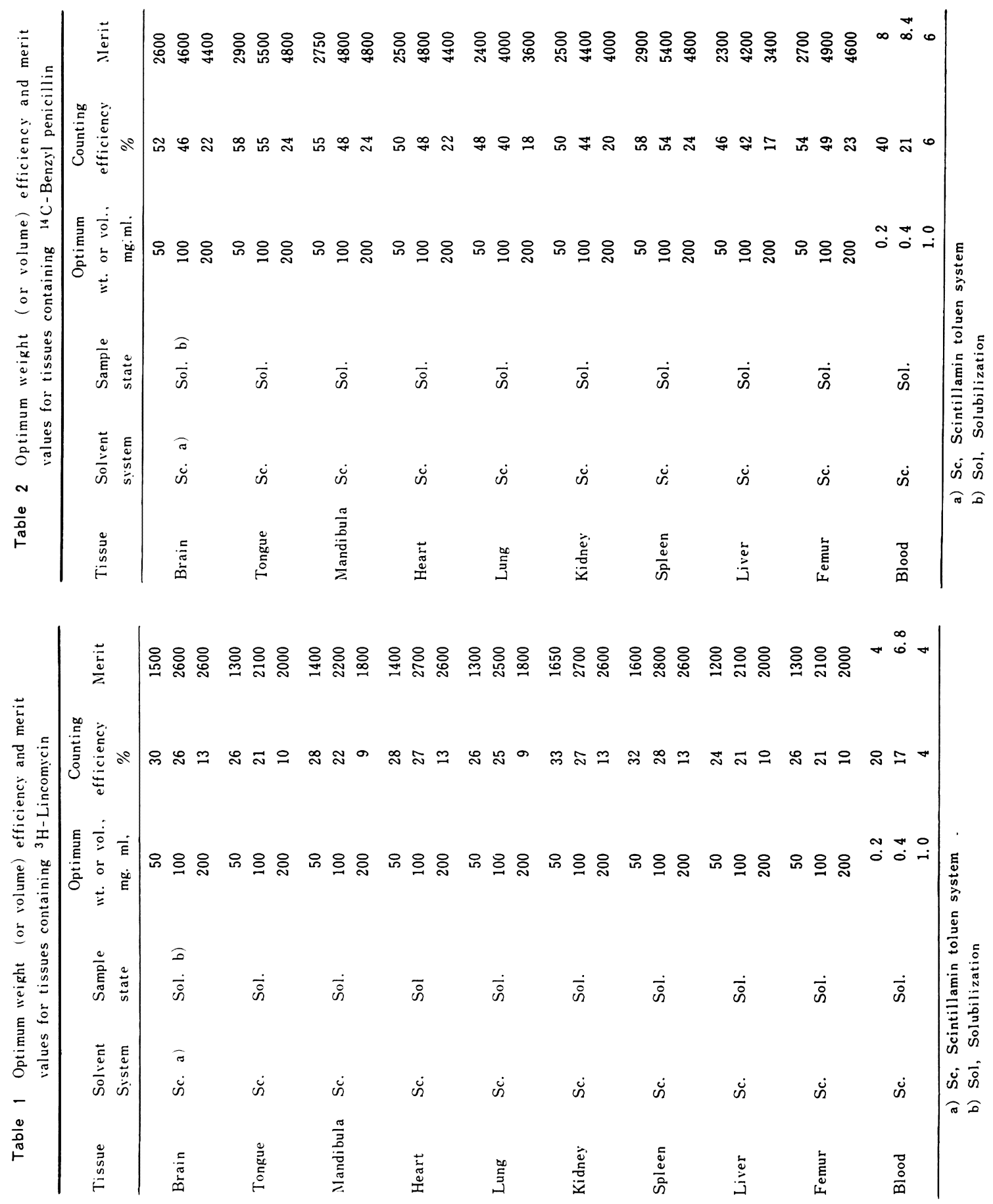
開発により薬物代謝研究領域でも，いわゆる低エネルギ 一の $\beta$ 線である ${ }^{14} \mathrm{C} ，{ }^{3} \mathrm{H}$ を標識した輠物が広く応用され， 夜体シンチレーションカウンターの普及に伴って, これ らの測定装继を利用しての標識抗生物質の蔵器, 組織内 分布の研究も報告されるよらになった.

一般に，標識抗生物質を動物に投与した際の生体内放 射活性分布の測定には，液体シンチレーションカウンタ 一が咕しているが, 测定のための生休試料（組織, 血液, 尿，排泄物等）の処理浩は繁雑をきわめている.それは, 生体陚料の処琹法において, 試薬の化学形に起因する quenching 現象などの弱点があり，特に動物を扱ら奌験 的研究において，組織中における ${ }^{14} \mathrm{C},{ }^{3} \mathrm{H}$ などを测定す る際の著しい障害とされている，そこで測定にあたって， できるだけ quenching 現象の少ない処䞏法を利用しな ければならない。

生体試料の処理法は, 測定武料を均一相で測定する場 合には, 1) Combustion counting 22) 25), 2) Solubiliz-

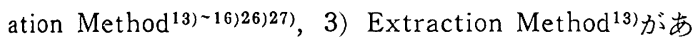
ク，不均一相で测定する場合には，4）Suspension counting ${ }^{28) 29)}$, 5) Paper Strip counting ${ }^{30)}$,6) Continuous Flow Measurment ${ }^{31)}$ らの種々な処琹法が報告されてい

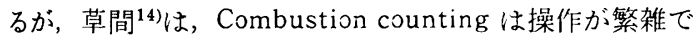
陚料が多いときは不便であると述べ，さらにSuspension Method は ${ }^{3} \mathrm{H}$ の場合において自己吸収の問題があり， 正確な測定は困難で着色試料による quenching が強い ので測定効洨の低下があると述べている．上田ら ${ }^{13)}$ Extraction Method は，組織などの処理には用いられる が，血液の場合は color quenching が強く，测定は困難 であると報告している. Paper Strip counting は, ${ }^{3} \mathrm{H}$ のような試料の処理法には適せず，定量的な值が得がた い欠点がある. Continuous Flow Measurmentは，測 定效率は ${ }^{14} \mathrm{C}$ で50\%以下， ${ }^{3} \mathrm{H}$ で $7 \%$ 以下と悪いため ${ }^{14)}$, 低放射能の試料に適しない. Solubilizattion Methodは, Herberg ${ }^{32)}$, Hall ${ }^{33)}$, Brown ${ }^{34)}$, 草間 ${ }^{16)}$, 東村 ${ }^{35)}$, 上田ら ${ }^{13)}$ ，によれば，比較的操作が容易で，すべての組 織に適用でき，水溶液性物質の測定に適し，测定効率も 割合と高いと報告している。

Solubilization Method による液体シンチレーション 测定には，生体試料をシンチレーターに溶解することが 前提となるが，組織はそのままの形では，シンチレータ 一に難溶であり，各種の溶解補助剤には， KOH-methanol, Hyamine $\mathrm{OH}, \mathrm{KOH}$-ethanol, Triton $\times 100, \mathrm{NaOH}$, $\mathrm{NcS}$ 等があるが, Herberg ${ }^{32}$ は, Hyamine $10 \mathrm{X}-\mathrm{OH}$ の 改良型であるシンチラミン $\mathrm{OH}$ 溶液は，シンチレーター
中に対する溶解度もよく, quenching 現象も少ないなど の利点があると報告している。

一般に，化学的 quencher であると言われているシン チラミン $\mathrm{OH}$ 溶液, 標識抗生物質水溶液, Toluen シン チレーターは，湘定効率を低下させるので契駼にあたっ て必要な籁囲で最低量に止めるべきである ${ }^{36)}$ と考えられ ている.

著者は、 ${ }^{3} \mathrm{H}$-Lincomycin, ${ }^{14} \mathrm{C}$-Benzyl penicillin の 2 種の標識抗生物質を尒備実験試薬として, シンチラミ ン $\mathrm{OH}$ 溶液量, Toluen シンチレーター溶液量, 標識抗 生物質水溶液量に打ける测定効染を娭討した。矢験成績 が示すごとく，化学的 quenching 現象を少なくし，か つ正確に测定するためには，動物に投与する ${ }^{3} \mathrm{H}$-Lincomycin 水溶液量扰よび ${ }^{14} \mathrm{C}$-Benzyl penicillin 水溶液量 は $0.5 \mathrm{ml}$ で, 組織溶解補助剤であるシンチラミン $\mathrm{OH}$ 溶液量は $1 \mathrm{ml}$, 测定用 Toluen シンチレーターは $7 \mathrm{ml}$ でありこの処理法を使用して ${ }^{3} \mathrm{H}$-Lincomycin の測定 効率は $37.5 \%,{ }^{14} \mathrm{C}$-Benzyl penicillin の測定效率は 65 $\%$ と, 他の溶解補助剂 $\left.{ }^{37}\right)$ と比較して，割合いと高い测定 効染を得た。

次に，添加生体試料は測定効率を低下させる着色クエ ンチャーとして影響するので添加組織量を検討したとこ 万, 組織 $50 \mathrm{mg}$, 血液 $0.2 \mathrm{ml}$ に颃いて測定効率は最高 であったが，Toluen 系における至適処理重量は Merit 值が最高となる組織 $100 \mathrm{mg}$ ，血液 $0.4 \mathrm{ml}$ であった。し かも, 組織 $100 \mathrm{mg}$, 血液 $0.4 \mathrm{ml}$ の涯加組織量の場合で も測定効率の低下はわずかであった。

以上の瑟由により，著者はシンチラミン $\mathrm{OH}$ 使用によ る Solubilization Method が，液体シンチレーション测 定法に適した方法であると考えたので，その結果につい て報告した。

\section{IV. 結論}

1）液体シンチレーションカウンター测定装置使用に よる標識抗生物質の体内分布に関する実験には，シンチ ラミン $\mathrm{OH}$ 溶液の Solubilization Method が使用できる.

2) Solubilization Method による液体シンチレーシ ョンカウンター測定には, 組織 $100 \mathrm{mg}$,（血液の場合は $0.4 \mathrm{ml})$ をシンチラミン $\mathrm{OH} 1 \mathrm{ml}$ を使用して $55^{\circ} \mathrm{C}, 24$ 時間恒温槽にて加效溶解し，その溶解液を $30 \%$ 過酸化水 素にて脱色し，Toluen 系シンチレーター $7 \mathrm{ml}$ にて測 定できる。

尚本論文の要旨は，昭和46年11月，第14回，日本口腔科学会 中部地方会, 昭和 47 年 4 月，第 26 回日本口腔科学会総会に才い て発表した。

稿を終るにあたり御指導，御校閲頂いた河合幹教授に深謝致 
しま寸。また種々御指導御助言頂いた生化学教室, 永律俊治教 授, 口腔衛生学教室条原幸夫助教授ならびに本研究に御協力下 さった服部孝䇛助教授ならびに教室員各位に深謝致します。

\section{参 考 文 献}

1）鳥居敏婎，他：重層法（1 次払散法）によるペニシリン 定量法に就いて. Journal of Penicillin 1:281 1947.

2）宮村定男, 他：莎网カップ法による体液中ペニシリン及 びストレプトマイシン濃度测定法. J Antibiotics 3： 4111950.

3）古川牧一：抗生物質の定量，体内分布並びに腎排出に関 寸る研究, 特に研究方法の新考条, 第 1 編, 抗生物質の 1 新生物学的微显简易定量法「带培羡法」の研究. 派進 医学: 8:703 1956 .

4) Heatley, N.G: A method for the assay of penicillin. Biochem J 38:61 1944 .

5) Boniger, Berichte der Deut. Chem. Gesellschaft. $27: 25$ 1938. (真下哲明 : 日新医学 $36: 4011949$ より 引用)

6）土屋文雄，他：Sulfonmid 化合物の吸収，排沚並びに 体内分布について. 泌尿誌 $46: 4521939$.

7) 栗秋 要, 他: Josamycin の研究VI, Josamycin の吸 収および体内分布に関する砄究. J Antibiotics 22:226 1969.

8) Sullivan, H.R, et al. : Metabolism of cephalexin${ }^{14} \mathrm{C}$ in mice and in rats. J Antibiotics. 20:195 1969.

9) Sullivan, H.R, et al. : Metabolism of D-cephaloglycin ${ }^{-14} \mathrm{C}$ and $\mathrm{L}$-cephloglycin- ${ }^{-14} \mathrm{C}$ in the rat. J Antbiotics. 22:27 1969 .

10）清水喜八郎, 他：化学療法剤の体液濃度の意義. 最新医 学 $24: 18261969$.

11) Ulberg, S., et al. : Am J Vet Res. 19:84 135 1958.（化学の領域 增刊 95 号 isotope による蒋物代謝 実娩. 南江堂, 東京. 1971. p 136. より引用

12) Funke, H. : Acta Vet Scand Suppl. $2: 1$ 1961. (化 学の領域 增刊 95 号 isotope に上万楽物代謝実䮖. 南江 堂, 東京. 1971.p 136. より引用

13）上田英崔, 他：液体シンチレーション計测における医学: 処理法について. 最新医学 21:2513 1966.

14）草间境一：液体シンチレーションカウンターによる生体 物質の测定について.生物物䧉 7：31 1967.

15）草间度一：液体シンチレーションカウンターによる生体 物質の水溶液の新测定法. Radio isotopes 14: 145 1965.

16) Brown, W.O. et al. : Liquid scintillation counting of $\mathrm{C}^{14}$-labelled animal tissues at high efficiency. Biochem. J $78: 5711961$.

17）大久保漟，他：諸種抗生物質の体内分布に関する研究。 日内会誌 $43: 5181954$.

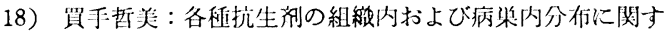
万研究. Chemot erapy 11:4257 1963.
19）中山脩郎：抗生剤の藏器内濃度に関する研究. 慈医誌 $72: 8011957$.

20）藤本安男 : 諸種生物質の溦器内分布之胆计内排泄態度に 関する研究, 第 1 編, 諸種抗生物質の搭器内分布に関す 万研究. J Antibiotics 9:272 1956.

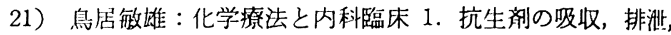
体内分布に関する砳究. 日内会誌 49:908 1960.

22) Kelly, R.G. et al. : Determination of ${ }^{14} \mathrm{C}$ and ${ }^{3} \mathrm{H}$ in biological samples by schoniger combustion and liquid scintillation iechniques. Analy Biochem 2: 2671961.

23）樫田義彦，他：液体シンチレーションスペクトロメータ 一による ${ }^{14} \mathrm{C},{ }^{3} \mathrm{H}$ の测定 (VI) 酸素フラスコ燃㶿法によ る㥀物組織中の ${ }^{14} \mathrm{C}$ の測定. Radioisotopes 14:331 1965.

24）馬場茂崔，他：液体シンチレーション計数装置による生 体試料中の ${ }^{3} \mathrm{H}$ の测定法. 菂学雑誌 $87: 8301967$.

25) Gupta, G.N. . A simple in vial combustion method for assay of hydrogen-3, cabon-14, and suIfur-35 in biological, and organic materials. Anal Chem 38: 13561966.

26）滝口久：液体シンチレーションカウンタ一用のカクテ ルの処方とその使い方. 歯界展望：39:773 1972.

27）樫田義浐，他：液体シンチレーション测定法の最近の進 步, 新しい試料調整法. Radioisotopes 19:41 1970.

28) Hayes, F.H, et al. : Conuting suspension in liquid scintilation. Nucleonics. No. 3. 48, 1956.

29) Rapkin, E. : Suspension counting. Pachard Technical Bulletion No. 5. 1963.

30) Roucayrol. J, et al. : Liquid scintillation counting of paper chromatography. Biochem Biophys Res comm 1: 2031959.

31) Rapkin, E. : Continuous flow measurment. Pachard Technical Bulletion No. 11. 1963.

32) Herberg, R.T. . Determination of caborn-14 and tritium in blood and other whohl tissues. Analytical chemistry. $32: 421960$.

33) Hall, T.C. : High-efficiency liquid scintillation counting of ${ }^{14} \mathrm{C}$-labelled material in aqueous solution and determination of specific activity of labelled proteins. Biochem J 96:626 1965 .

34) Brown, W.O. . Liquid Scintillation Counting of ${ }^{14} \mathrm{C}$-labelled animal tissue at high efficiency. Biochem J $78: 5711961$.

35）查村武信，他：放射性同位元素取り报い（液体シンチレ ーションカウンターについて） 4. 测定試料の調製法, 続生物物理学集座 3. 吉岡苫店, 京都, 1968. p 264.

36）樫田義浐, 他 : Liquid scintillation counting の最近 の進步. Radioisotopes 14:152 1965.

37）樫田義彦：㪄射線の测定（II），低エネルギーベーター 線の测定, 液体シンチレーションによる测定法(I ). Radioisotopes $16: 851967$. 